Scientia Marina 71(2)

June 2007, 305-314, Barcelona (Spain)

ISSN: 0214-8358

\title{
Origin and abundance of beach debris in the Balearic Islands
}

\author{
LORENA MARTINEZ-RIBES, GOTZON BASTERRETXEA, MIQUEL PALMER \\ and JOAQUÍN TINTORÉ.
}

Instituto Mediterráneo de Estudios Avanzados (CSIC-UIB), Miquel Marqués 21, 07190 Esporles, Spain.

E-mail: viealmr4@uib.es

\begin{abstract}
SUMMARY: The abundance, nature and possible sources of litter on 32 beaches on the Balearic Islands (Mediterranean Sea) were investigated in 2005. Mean summer abundances in the Balearics reached approximately 36 items $\mathrm{m}^{-1}$, with a corresponding weight of $32 \pm 25 \mathrm{~g} \mathrm{~m}^{-1}$, which is comparable to the results of other studies in the Mediterranean. Multivariate analyses (principal component analysis and redundancy analysis) confirmed strong similarities between islands and a statistically significant seasonal evolution of litter composition and abundance. In summer (the high tourist season), debris contamination expressed as item abundance was double that in the low season and showed a heterogeneous nature associated with beach use. Cigarette butts were the most abundant item, accounting for up to $46 \%$ of the objects observed in the high tourist season. In contrast, plastics related to personal hygiene/medical items were predominant in wintertime (67\%) and natural wood was the most important debris by weight (75\%). In both seasons, litter characteristics suggested a strong relationship with local land-based origins. While beach users were the main source of summer debris, low tourist season litter was primarily attributed to drainage and outfall systems.
\end{abstract}

Keywords: Balearic Islands, beach, debris, litter, Mediterranean Sea, tourism.

RESUMEN: ORIGEN Y ABUNDANCIA DE RESIDUOS EN PLAYAS DE LAS ISLAS BALEARES. - En un estudio realizado durante el año 2005 se analizó la abundancia, naturaleza y posibles orígenes de los residuos presentes en 32 playas de las Islas Baleares (mar Mediterráneo). La abundancia media de objetos en verano fue de aproximadamente 36 objetos por metro lineal, con un peso correspondiente de $32 \pm 25 \mathrm{~g}$ por metro lineal, lo cual es comparable a otros estudios en el Mediterráneo. El estudio mediante análisis multivariantes (Análisis de Componentes Principales y Análisis de Redundancia) confirma importantes similitudes entre islas, además de una evolución estacional estadísticamente significante en la composición y abundancia de los residuos. La contaminación durante el verano, expresada en términos de abundancia de objetos en la playa, duplica el valor registrado en invierno. Además, los objetos hallados durante esta época son de naturaleza heterogénea lo que se asocia con los vertidos realizados por los usuarios de las playas. De lo recogido en verano, las colillas son el residuo más abundante, alcanzando un $46 \%$ de los objetos observados. Por el contrario, los plásticos, y en particular los relacionados con el aseo personal y las medicinas son el tipo de objeto más común en invierno $(67 \%)$ y las maderas representan el tipo de residuo más abundante en cuanto a peso (75\%). En ambas estaciones, los residuos encontrados muestran una estrecha relación con fuentes de tipo local; mientras que los usuarios de las playas son el mayor foco de residuos en el verano, en invierno éstos se asocian con los sistemas de alcantarillado y emisarios.

Palabras clave: Islas Baleares, playa, residuos, basura, mar Mediterráneo, turismo.

\section{INTRODUCTION}

The presence of litter in the marine environment is a well-recognised problem related to increasing anthropogenic pressure on the world's coasts affecting terrestrial and marine ecosystems, causing dam- age to marine organisms and their habitats, and also affecting human activities. These considerable environmental problems have drawn the attention of the scientific community over the last few decades, resulting in a number of research monitoring programmes (e.g. UNEP with its Mediterranean Action 
Plan, 1975; the OSPAR Convention, 1992). Likewise, international and regional conventions and legislation have been adopted by riparian countries and communities with the aim of mitigating marine pollution (e.g. MARPOL, 1973; HELCOM, 1974; the Barcelona Convention, 1976).

The problems generated by marine litter can be attributed to both the amount of debris generated and its nature (Frost et al., 1997). Beaches are areas where objects originating from different sources and transported by currents, waves and wind action tend to accumulate. Amongst the debris usually found along the shore, slowly degrading materials such as plastics and wood are typically the most abundant types (e.g. Merrell, 1980; Kusui et al., 2003). These long-lasting objects may benefit the expansion of marine organisms, including exotic species (Masó et al., 2003; Aliani et al., 2003a; Barnes et al., 2005), damage coastal economic activities such as fisheries, and affect marine fauna by entanglement and ingestion (Laist, 1987; Sazima et al., 2002).

The nature and abundance of beach debris can be related to both terrestrial and marine-based activities, whose relative importance varies regionally. Maritime sources of litter are associated with ships, recreational boats and offshore installations such as fish-farms and oil extraction platforms, whereas terrestrial-based sources include rivers, drainage systems, landfill sites and beach users. The typology of items found in the literature relates the quantity of marine litter to the inadequate handling of solid wastes, which can remain in the environment for long periods and be transported over long distances by winds, rivers and marine currents (Vauk et al., 1987; Silva-Iñiguez et al., 2003). Shipping-related activities (Dixon et al., 1981; Vauk et al., 1987), commercial fishing (Otley et al., 2003; Edyvane et al., 2004) and waterborne sources (Stefatos et al., 1999; Moore et al., 2001) have been reported as the origin of litter. However, in areas with intensive beach usage, there is evidence that direct inputs by beach goers can significantly contribute to a deterioration of the coastal environment (Willoughby, 1986; Velander et al., 1998).

Enclosed seas such as the Mediterranean are far more sensitive to anthropogenic pressures than open oceanic areas. The population increase along the Mediterranean coast has been paralleled by an increase in coastal and nearshore debris, which can remain in its waters for long periods of time. Studies in the Mediterranean reveal that land-based activities and shipping lanes produce most of the litter (Galil et al., 1995; Stefatos et al., 1999; Aliani et al., 2003b), with higher abundance of marine debris related to densely populated and highly industrialised areas (e.g. Katsanevakis et al., 2004). The influence of urbanised areas has also been found on the European continental shelf (Galgani et al., 2000) and on Mediterranean beaches (Gabrielides et al., 1991).

Tourists associate the presence of wastes along the coast with polluted beaches and poor water quality (Dinius, 1981), and hence littered beaches are a major deterrent to tourism. For small tourist islands such as the Balearics this problem is particularly acute because the economy is largely dependant on the increasing recreational use of the coast. Additionally, most of the local population lives in the vicinity of the coast, and hence is directly affected by coastal degradation. This has raised concern among local authorities, managers and stakeholders, who perceive litter as a major environmental problem, so costly efforts are made to keep beaches clean. However, few studies have made a quantitative assessment of litter characteristics in insular areas.

In this paper, the nature, abundance and possible origin of beach debris in the Balearic Islands is quantitatively addressed, and the importance of the sources of litter on the shore is analysed. Sampling of debris was carried out along the Balearic coasts in 2005. With some exceptions, the coastal areas of the archipelago are essentially dedicated to the tourist industry and the resorts are concentrated in the vicinity of beaches in what has been called the 'sun and beach model'. In the Balearics, coastal industrial activity is low, riverine inputs are non-existent and sporadic runoff occurs during major storm events. Although tourist visits are received throughout the year, high beach usage is restricted to the summer months when up to 11 million people visit the Balearic coastal resorts (source: Instituto Balear de Estadística). In this season, sandy beaches of intensive use are regularly cleaned by the local municipalities.

\section{MATERIALS AND METHODS}

The Balearic coast was divided into 9 different zones according to their main orientation. A general survey comprising 32 randomly selected beaches ( 3 or 4 per zone) was conducted in July 2005 (Fig. 1 and Table 1). With the exception of beach no. 14 (a cobble beach located in a remote area with difficult access), all beaches shared the common characteris- 

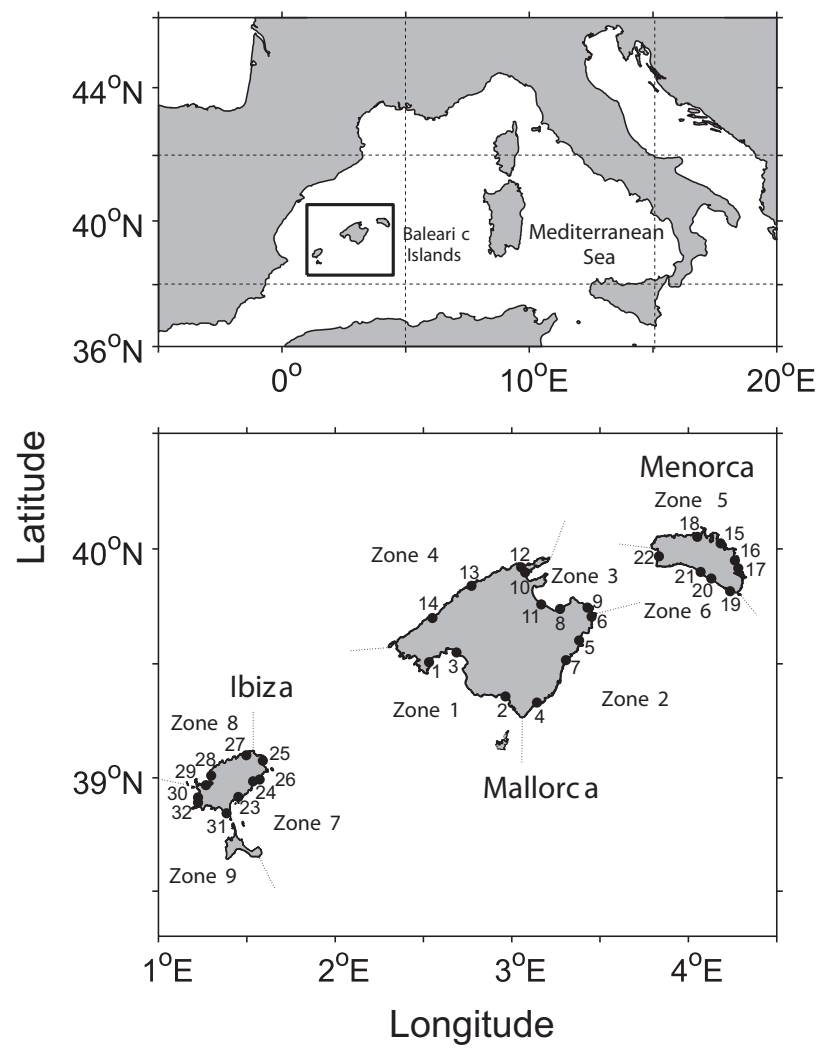

FIG. 1. - Map of the Balearics showing the locations of the sampling sites and the zone divisions used for this study.

tics of being sandy beaches near villages or tourist resorts. Each survey consisted of five 2 m-wide transects perpendicular to the shoreline extending from the waterline to the backshore, $15 \mathrm{~m}$ apart from each other (between 200 and $400 \mathrm{~m}^{2}$ depending on beach width). According to Williams et al. (1999), $85 \%$ of the number of debris species would thus be covered. As in other studies, debris concentrations were expressed as integrated values per unit of beach front (e.g. Jones, 1995; Willoughby et al., 1997; Debrot et al., 1999). This notation was selected as most suitable for intercomparison purposes since litter was generally found unevenly distributed across the beach (mostly stranded and/or accumulated by wave action in the waterline). The upper few centimetres of the surface to be surveyed were raked to lift all semi-buried debris up to the surface and then sieved with a $1 \mathrm{~mm}$ mesh. Raked surfaces were measured and recorded in order to normalise the values obtained on all beaches.

Collected items were identified, classified, counted and weighed. Two classification methods were used according to composition and origin (see Appendix). Wooden building waste and other wood products such as painted woods, boat pieces and bulky items were classified as wood debris, but tree trunks and branches constituted a separate classification. Smoking-related activities were a group on their own given the large number of cigarette butts found.

To analyse temporal differences in debris abundance, monthly measurements were carried out in Mallorca (zones 1-4) during the high tourist season (June to September). Additionally, a survey was undertaken during the low tourist season (April). All surveys were carried out early in the morning, before cleaning activities took place and tourists occupied the beach.

A multivariate statistical approach (Redundancy analysis, RDA; ter Braak et al., 2002) was used to test whether there were significant differences regarding the composition of debris between the three islands considered. Similarly, between-month differences and beach orientation differences were evaluated. RDA

TABLE 1. - Litter survey sites and codes as referred to in text and figures. The degree of tourist occupation was obtained from the Ministry of Environment.

\begin{tabular}{|c|c|c|c|c|c|c|c|c|c|}
\hline Code & Name & Occup. & Lat. (N) & Lon. (E) & C. & Name & Occup. & Lat. (N) & Lon. (E) \\
\hline 1 & Magalluf & High & $39^{\circ} 30^{\prime}$ & $2^{\circ} 32^{\prime}$ & 17 & Mesquida & Medium & $39^{\circ} 55^{\prime}$ & $4^{\circ} 17^{\prime}$ \\
\hline 2 & Covetes & High & $39^{\circ} 21^{\prime}$ & $2^{\circ} 58$ & 18 & Binimel.la & Low & $40^{\circ} 03$ & $4^{\circ} 03$ \\
\hline 3 & Es Penyò & High & $39^{\circ} 33$ & $2^{\circ} 41$ & 19 & Binibeca & Medium & $39^{\circ} 49^{\prime}$ & $4^{\circ} 14^{\prime}$ \\
\hline 4 & Santanyí & High & $39^{\circ} 20^{\prime}$ & $3^{\circ} 09^{\prime}$ & 20 & En Porter & High & $39^{\circ} 52$ & $4^{\circ} 08^{\prime}$ \\
\hline 5 & Cala Millor & High & $39^{\circ} 36^{\prime}$ & $3^{\circ} 23$ & 21 & Son Bou & High & $39^{\circ} 54^{\prime}$ & $4^{\circ} 04^{\prime}$ \\
\hline 6 & Son Moll & High & $39^{\circ} 42^{\prime}$ & $3^{\circ} 27^{\prime}$ & 22 & Blanca & High & $39^{\circ} 58^{\prime}$ & $3^{\circ} 50^{\prime}$ \\
\hline 7 & Estany Mas & High & $39^{\circ} 31^{\prime}$ & $3^{\circ} 19^{\prime}$ & 23 & Talamanca & High & $38^{\circ} 55^{\prime}$ & $1^{\circ} 27^{\prime}$ \\
\hline 8 & St. Pere & Low & $39^{\circ} 44^{\prime}$ & $3^{\circ} 16^{\prime}$ & 24 & Sta. Eulalia & High & $38^{\circ} 59$ & $1^{\circ} 32$ \\
\hline 9 & Mesquida & High & $39^{\circ} 45^{\prime}$ & $3^{\circ} 26^{\prime}$ & 25 & St. Vicenç & High & $39^{\circ} 04^{\prime}$ & $1^{\circ} 35$ \\
\hline 10 & Llenaire & High & $39^{\circ} 54^{\prime}$ & $3^{\circ} 05$ & 26 & $\mathrm{Ca} \mathrm{Na}$ Martina & High & $38^{\circ} 59$ & $1^{\circ} 34^{\prime}$ \\
\hline 11 & Son Bauló & High & $39^{\circ} 45^{\prime}$ & $3^{\circ} 10^{\prime}$ & 27 & Xarraca & Low & $39^{\circ} 06^{\prime}$ & $1^{\circ} 30^{\prime}$ \\
\hline 12 & Molins & High & $39^{\circ} 55^{\prime}$ & $3^{\circ} 03$ & 28 & Salada & Low & $39^{\circ} 00^{\prime}$ & $1^{\circ} 18^{\prime}$ \\
\hline 13 & Sóller & High & $39^{\circ} 50^{\prime}$ & $2^{\circ} 46^{\prime}$ & 29 & Es Torrent & High & $38^{\circ} 58^{\prime}$ & $1^{\circ} 16^{\prime}$ \\
\hline 14 & Canonge & Low & $39^{\circ} 42^{\prime}$ & $2^{\circ} 33$ & 30 & Vedella & Medium & $38^{\circ} 55^{\prime}$ & $1^{\circ} 13$ \\
\hline 15 & Castell & Medium & $40^{\circ} 01$ & $4^{\circ} 11^{\prime}$ & 31 & Ses Salines & Medium & $38^{\circ} 50^{\prime}$ & $1^{\circ} 23$ \\
\hline 16 & Es Grau & Medium & $39^{\circ} 57^{\prime}$ & $4^{\circ} 16^{\prime}$ & 32 & d'Hort & Medium & $38^{\circ} 53$ & $1^{\circ} 13$ \\
\hline
\end{tabular}


can be considered the multivariate extension of univariate analysis of variance (ANOVA). Prior to these inferential statistical analyses, conventional descriptive multivariate analyses (principal components analyses, PCAs) were completed. The PCAs were intended to resume high-dimensionality data (i.e. 13 categories of debris in 32 beaches) in a simpler (usually two-dimensional) space. The aim was to interpret major trends of similarities between sites and the major correlational patterns between abundances of types of debris. This descriptive approach has been successfully used in other beach litter studies (Tudor $e t$ al., 2002; Williams et al., 2003).

Both the PCAs and the RDAs were completed using CANOCO (ter Braak et al., 2002). All multivariate analyses focused on the relative composition of debris rather than on the absolute amount of items. Therefore, between-survey similarities were based on correlations rather than on variancecovariance (as in Williams et al., 2003). Concerning RDA, multivariate data rarely meet the normality assumption needed to estimate the probability that the observed data may be obtained under the null hypothesis. Consequently, an intensive permutation Monte Carlo approach was adopted. The specificities of the three hypotheses (i.e. differences between islands, orientation and seasons) were emulated using the nested permutation capabilities of CANOCO (ter Braak et al., 2002).

\section{RESULTS}

\section{Litter abundance}

The visual appearance of the beaches in the Balearics during the summer was generally good, since cleaning activities took place on a daily basis. The largest debris in size was in the vicinity of rubbish bins, which were usually full at the end of the day, and was mainly composed of beach mats and rubber floats. Stranded small sized items were most visible on the high water line and were usually mixed with remnants of the endemic seagrass Posidonia oceanica.

A total amount of $10 \mathrm{~kg}$ and 11231 items were collected in the nine zones during the general survey in July. Mallorca, which is host to $80 \%$ of the population and $70 \%$ of the visitors, contributed $54 \%$ of the total weight collected and $51 \%$ of the total number of items.
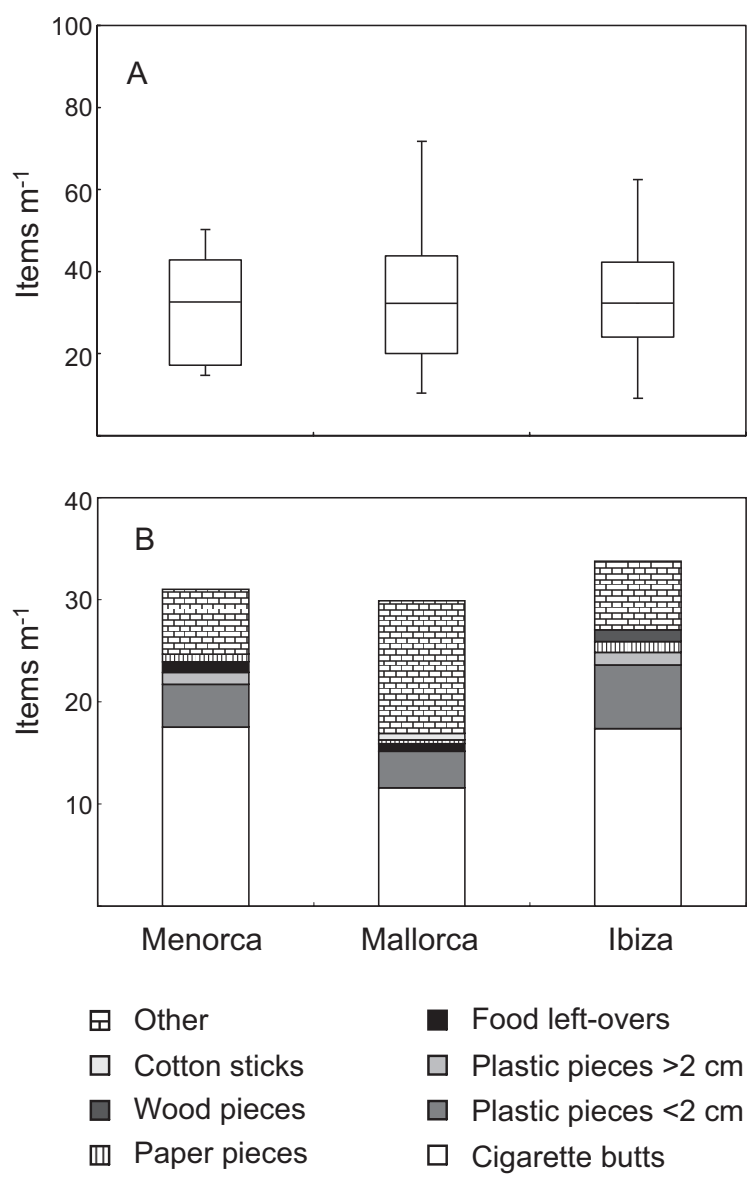

FIG. 2. - A, box plots of the average number of items per linear metre with associated standard deviations collected in Menorca, Mallorca and Ibiza in July 2005. Upper boxes represent the $75 \%$ quartile, the lower ones the $25 \%$ quartile; $\mathrm{B}$, most abundant items per beach surveyed in the three Balearic islands during July 2005.

A comparison of item average abundance between islands revealed clear similarities (Fig. 2A). In the case of Menorca, the difference between quartiles was the highest, particularly given the extent of the $25 \%$ quartile. This shows that the data (in number of items per linear metre) were skewed in this case, whereas in Mallorca they were symmetrical and in Ibiza the $75 \%$ quartile was slightly wider than the $25 \%$ one. Higher litter contamination ( 132 items $\mathrm{m}^{-1}$ of beach front) was observed near densely populated urban areas (i.e. Palma $>20000$ inhabs. $\mathrm{km}^{-2}$ and Ibiza $>3800$ inhabs. $\mathrm{km}^{-2}$ ) and on geomorphologically constrained beaches. Conversely, cleaner beaches (i.e. 8 items $\mathrm{m}^{-1}$ ) generally corresponded to low-developed areas (i.e. Cala Xarraca and Cala Mesquida) and to the most exposed beaches where wave action and currents may disperse debris. Figure $2 \mathrm{~B}$ displays the items which were found in highest quantities on each island, with cigarette butts occupying the first position. Small plastic fragments were the second most frequent item, represent- 


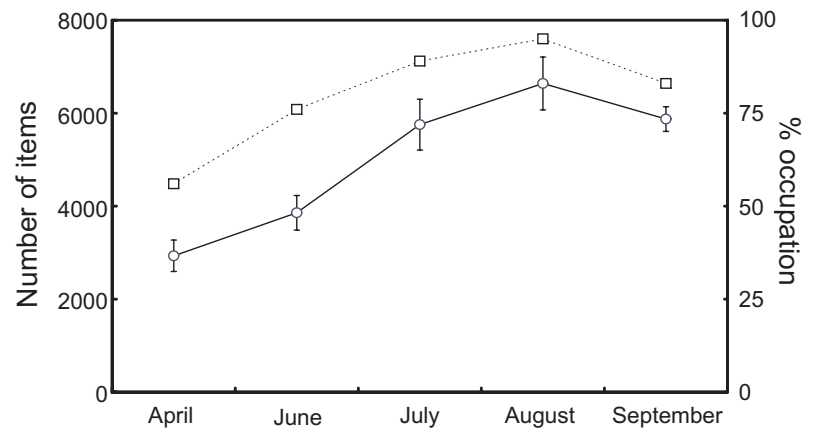

FIG. 3. - Monthly variation of mean $( \pm \mathrm{SD})$ number of debris items (open circles) and percentage of hotel occupation for the corresponding date (squares). Data from CITTIB, 2005.

ing $16 \%$ of all objects collected in the nine zones. Most of these plastic items were highly fragmented and degraded, and thus hardly identifiable. Strong fragmentation of plastic litter is claimed to be indicative of long retention time (Kusui et al., 2003).

The trends over time for Mallorca of item abundance and hotel occupation (\%) are depicted in Figure 3 . Debris values ranged from the approximately 3000 items collected in the low tourist season to the more than 6000 items in August. The trend of hotel occupation, which can be considered as an indicator of tourist activity, paralleled debris abundance, suggesting a relationship between beach usage and alongshore abundance of debris. It should be noted that wintertime values did not correspond to rain periods when runoff could significantly increase debris inputs.

A comparison of the abundance and weight of debris in each of the nine zones of this study

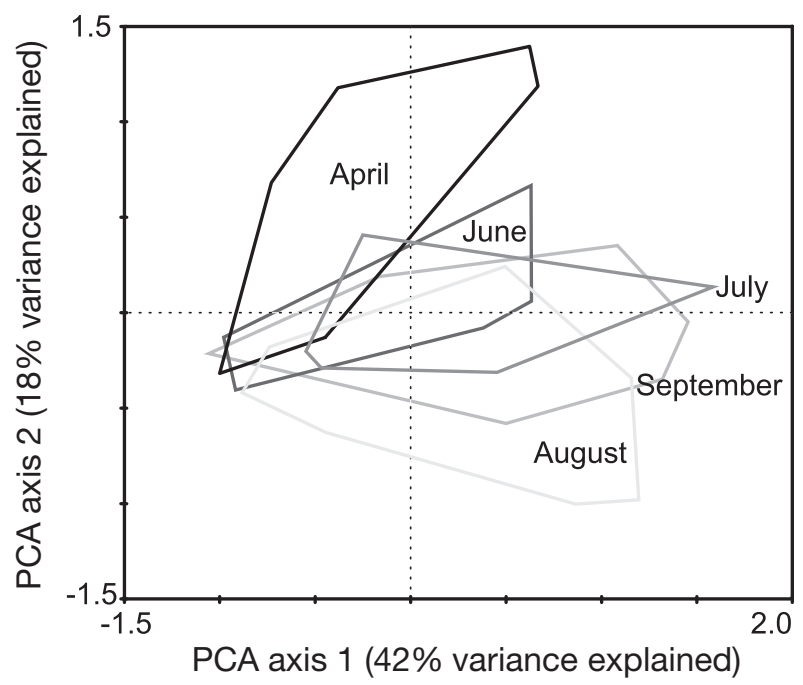

FIG. 4. - Plot of the principal component analysis of the temporal variability in beach litter abundance. The lines group the samples corresponding to the same month.
TABLE 2. - Total debris abundance (number of items and weight in grams) for July on the monitored beaches of Mallorca (zones 1-4), Menorca (zones 5-6) and Ibiza (zones 7-9) normalised to one linear metre of beach with their associated standard deviations (SD).

Zone No. of samples Items $\mathrm{m}^{-1} \pm \mathrm{SD} \quad$ Weight $\left(\mathrm{g} \mathrm{m}^{-1}\right) \pm \mathrm{SD}$.

\begin{tabular}{llll}
\hline 1 & 4 & $59 \pm 50$ & $33 \pm 27$ \\
2 & 4 & $36 \pm 17$ & $27 \pm 12$ \\
3 & 4 & $25 \pm 15$ & $29 \pm 14$ \\
4 & 3 & $39 \pm 28$ & $75 \pm 62$ \\
5 & 4 & $17 \pm 4$ & $26 \pm 8$ \\
6 & 4 & $44 \pm 4$ & $30 \pm 9$ \\
7 & 4 & $37 \pm 15$ & $37 \pm 19$ \\
8 & 3 & $35 \pm 27$ & $21 \pm 20$ \\
9 & 3 & $29 \pm 6$ & $18 \pm 8$
\end{tabular}

(Table 2) showed that most items were collected in the south and east of Mallorca (zones 1 and 2). This area included Palma, the most populated city where more than $48 \%$ of the island's population is concentrated (source: IBAE). The northern coast of Menorca (zone 5) had the lowest number of items, but large objects were found in this area, so it did not contain the lowest weight of debris (26 g $\mathrm{m}^{-1}$ ). Summer debris abundances in Mallorca were double those in the low tourist season $(38 \pm 12$ items $\mathrm{m}^{-1}$ in summer) but values of weights were considerably higher in winter. This difference in weight was explained by the abundant large remnants of natural wood found in winter.

Multivariate statistical analysis (RDA) did not reveal significant differences between the four zones of Mallorca, or between the nine zones of the archipelago $(\mathrm{P}>0.05)$. Thus, there was no change in the pattern of the presence of debris from one island to another and the geographic orientation among zones did not influence this pattern either. In contrast, statistically significant differences were found between months $(\mathrm{P}<0.05)$. These differences were visualised in the PCA plot (Fig. 4), which showed a temporal pattern in the relative composition of beach debris (number of items per group). A high variation in this factor was indicated by the irregular shape of the surface for each month in the plot, generated by the distribution of the different groups. The groups of items considered for completing these analyses are listed in Table 3.

\section{Litter composition}

The relative abundance of the different types of debris for Mallorca in 2005 is displayed in Figure 5. Debris was generally composed of small fragments $(<5 \mathrm{~cm})$ and only occasionally ( $1 \%$ of the total items) 
TABLE 3. - Groups of items selected for the multivariate analyses.

\begin{tabular}{ll}
\hline Group & Items included \\
\hline Drinking & Bottles, cups, straws, tins, bottle rings, tops, glass fragments \\
Food & Food leftovers, wrappers, cutlery, toothpicks, ice and sweets sticks \\
Users (left items) & Shoes, newspapers, clothing labels and items, recently used batteries, coins, balloons, medicines \\
Personal hygiene/medical items (sewage) & Cotton bud sticks, hygienic towels, tampons and applicators \\
Smoking & Cigarette butts, tobacco packets, lighters \\
Fishing & Pieces of net, fishing gear, rope, pieces of cork \\
Building & Concrete fragments, metal cables, tubes, pipe fragments \\
Dead animals or remains & Egg shells, bones, dead animals \\
Styrofoam & Pieces of white plastic boxes \\
Plastic pieces & Unidentified pieces of plastic \\
Natural wood & Branches or trunks \\
Processed wood & Pieces of boats, placards, signs \\
Plastic bags & \\
\hline
\end{tabular}

large items were observed (bricks, bodice, pieces of wood). In wintertime, when there were few beachgoers, debris was mainly composed of pieces of plastic. Cotton bud sticks, found on most of the beaches, were the most abundant item within the plastics, and were particularly numerous in some areas (e.g. Es Penyò beach), where up to 42 items $\mathrm{m}^{-1}$ were counted. Cigarette butts were frequent ( 5 items $\mathrm{m}^{-1}$ ), although markedly less than in summer $\left(17\right.$ items $\left.\mathrm{m}^{-1}\right)$.

Generally, debris composition was more heterogeneously distributed in the summertime, when there was also a wider variety of items. The dominant group in the high tourist season (i.e. 'Other') included materials of heterogeneous nature (cigarette butts, batteries, building fragments). Amongst these, cigarette butts were the most frequently observed items (56\% of the group), with occurrences on all sampled beaches. Maximum butt densities (up to 68 items $\mathrm{m}^{-1}$ ) were observed on an urban beach located on the eastern coast of Mallorca. Wood debris, although comprising $75 \%$ the weight of debris in the wintertime, only accounted for $2.8 \%$ of the number of objects. Despite scavengers (principally seagulls) feeding on leftovers, the abundance of rapidly degrading material such as

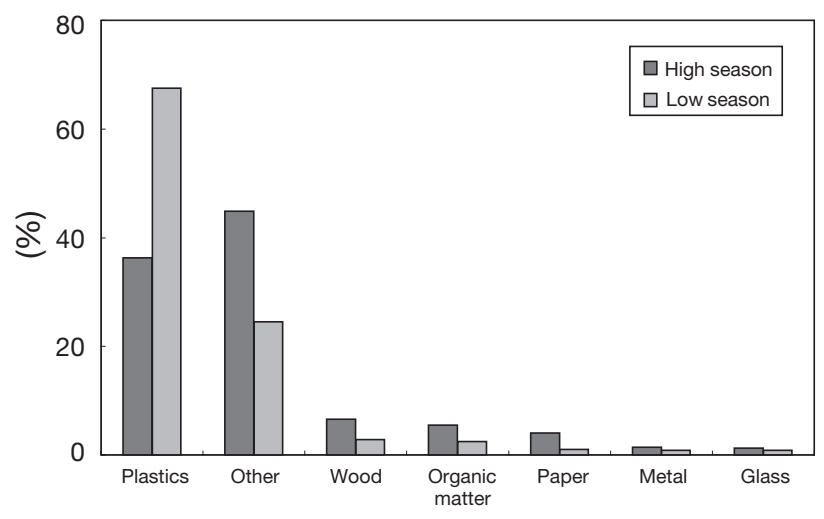

FIG. 5. - Litter composition in low and high tourist season. organic matter was significant. This type of litter accounted for up to $5.5 \%$ of number of items in summer. Scarcely degraded paper items such as tickets, napkins and wrappers from nearby shops and bars were also frequent.

A further PCA analysis was performed to distribute the surveyed beaches along the same axis according to the groups of items collected on them (refer to Table 3), in order to identify the existence of any clustering pattern (Fig. 6). Figure 6A presents an outlier (no. 14) corresponding to a cobble beach located on the north coast of Mallorca which was relatively unfrequented due to access difficulties. The analysis also revealed a small group of three beaches (nos. 3, 8 and 13), all in Mallorca, which are close to urban centres. A second cluster included beaches $6,9,12,18,22$ and 27 , which are all but one facing north, and were characterised by the number of smoking items (mainly cigarette butts) and pieces of plastic. The rest of the beaches were placed close to the zero point, and there was no significant difference among them with respect to the number and types of items collected. Thus, as followed from the initial statistical results, there were no sharp differences between the beaches.

The correlational plot among items (Fig. 6B) indicated that there were some groups that had a different distribution to others, and these were hence separated. For instance, dead animals, plastic bags and Styrofoam were not found on all beaches, and when they were, only a few items were collected. Another group on its own was building material, which only occurred in areas that were close to construction sites or on recently renewed sites, and included pieces of bricks or plastic tubes. Pieces of plastic were numerous on all beaches, ranging from 0.3 to 37 items $\mathrm{m}^{-1}$. Food leftovers, items left by 


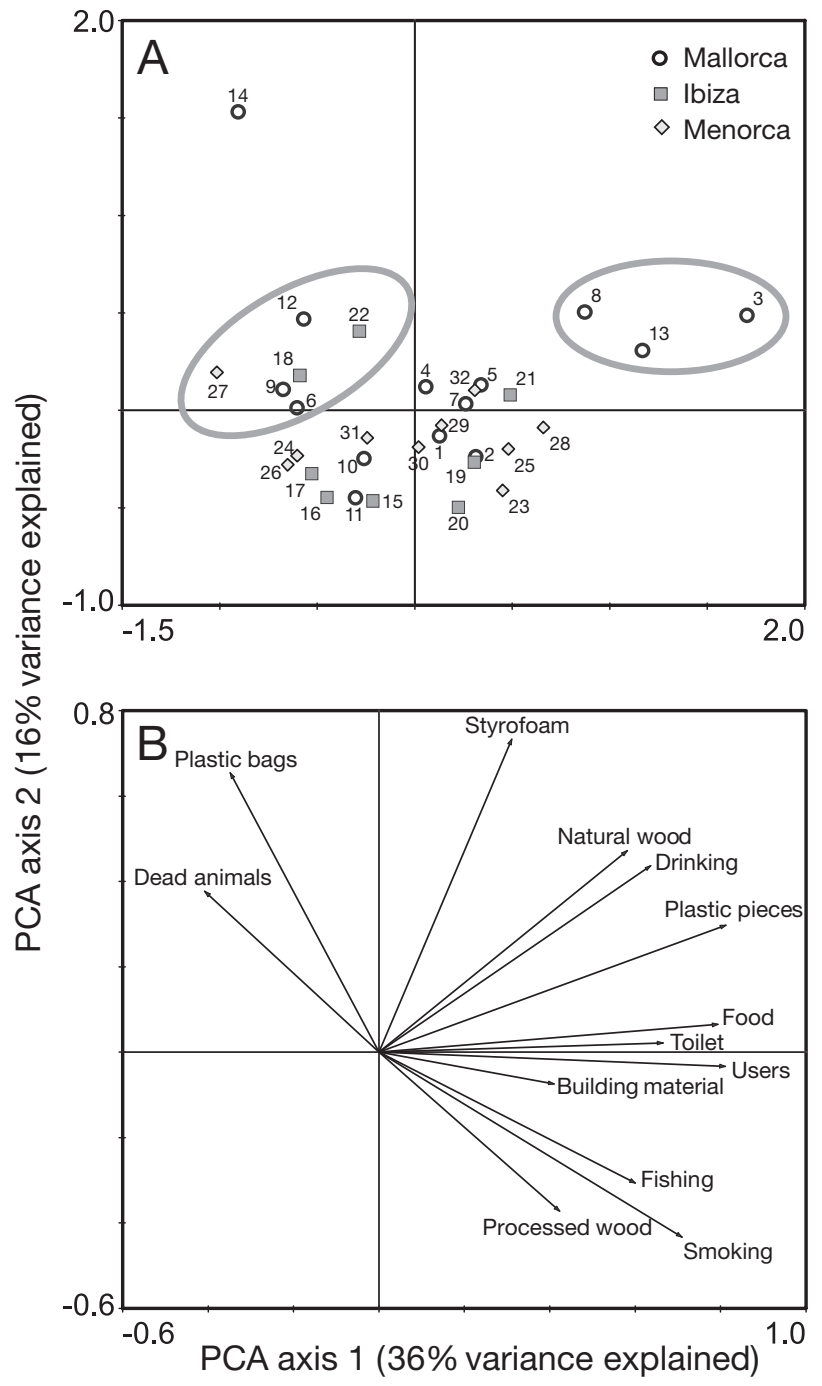

FIG. 6. - A, plot of the principal component analysis of survey sites using group classification of Table $3 ; \mathrm{B}$, plot of the variables corresponding to the analysis in Figure 6A. Small angles between arrows indicate positive high correlations between groups.

beach users and toilet debris (related to sewage systems) were grouped together, which can be explained by the high number of visitors occurring on those beaches close to urban centres, which usually have sewers nearby. Processed wood and fishing litter were together with smoking-related items, even though the latter was the most abundant group on almost all beaches. The values for the smoking group ranged from 1 item $\mathrm{m}^{-1}$ on beach 14 to 46 items $\mathrm{m}^{-1}$ on a highly visited beach close to Palma (beach 3).

\section{Estimated origin}

The main type of debris collected during the high season $(43.8 \%)$ on the sampled beaches of

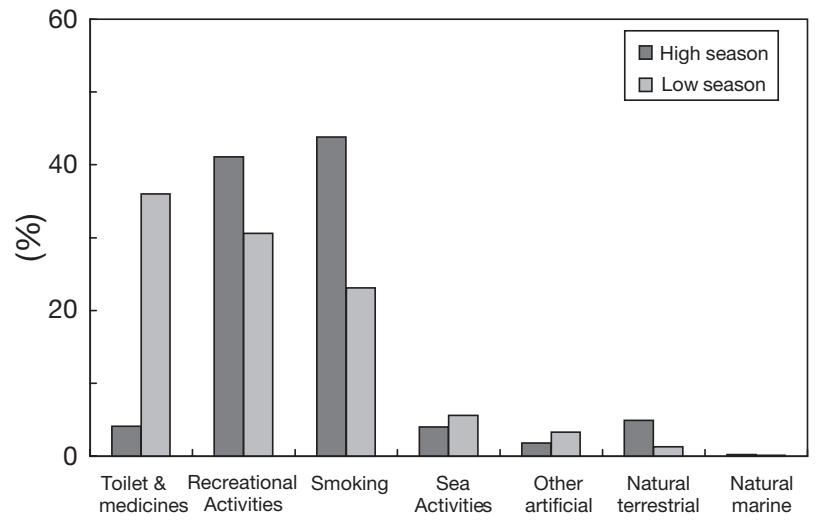

FIG. 7. - Estimated origin of the litter collected in low and high tourist season.

Mallorca was attributed to the smoking group (see Fig. 7), composed not only of cigarette butts but also of the plastics that wrap the packets, lighters, matches and empty packets. A secondary source (41.1\%) included activities on the shore or recreational activities. Other sources were significantly lower (between 0.2 and $4.9 \%$ ) and, strikingly, natural marine debris accounted for only $0.2 \%$ (Posidonia oceanica leaves which can be occasionally significant were disregarded). This type of debris was mainly represented by bones of Sepia officinalis, which has its reproductive cycle from spring to late July, after which it dies (Guerra, 1992). Within the group personal hygiene/medical items $(4.1 \%)$, on certain beaches there was a great abundance of cotton bud sticks, which have been related to sewage systems (Velander et al., 1998; Ribic, 1998). This kind of debris notably became the most abundant litter source in winter. The activities on the shore were still important, at almost $31 \%$, and their contribution in weight $(49 \%)$ was particularly high. Wood items of terrestrial origin, although low in number (1\%), constituted the most important source in weight during winter.

\section{DISCUSSION AND CONCLUSIONS}

Though beach litter levels are not critical on the Balearic Islands, they are of great concern to local authorities, particularly during the summer months when tourist occupation is highest. This is because cleanliness is recognised as the most important factor in influencing choice of beach, especially for foreign tourists (Ballance et al., 2000). Additionally, the perception of the quality of the Balearic Islands as a des- 
tination is mirrored by the environmental state of the beaches and beach cleaning implies costly economic efforts. In this study, the main source of high season debris in the Balearics was due to direct inputs by beach-users, who generate more than $80 \%$ of what is collected on the shore (waste from activities on the shore or recreational and smoking debris). This result is supported both by the temporal trend of litter abundance, which follows that of tourist occupation, and by the litter type which, with some exceptions (i.e. small plastic pieces), suggests a recent and land-based origin related to recreational activities.

As expected, strong similarities in litter abundance among the different areas or islands were observed since the majority of the coasts of the archipelago are devoted to the tourist/recreational sector and beachgoers carry out comparable activities. An exception was beach 14 (Port des Canonge) where both litter abundance and relative composition were different as revealed by PCA analysis. The differences from the other beaches in litter abundance were attributed to the lower frequentation of this beach due to access difficulties and the users' preference for sandy beaches. However, these two factors did not explain the differences in litter composition. Explanations for these differences are a difference in substrate composition (boulder and cobble on beach no. 14), which allows deep penetration of small objects; the low number of nearby tourist facilities such as restaurants and shops, and the fact that mechanical beach cleaning is impossible. Indeed, Williams and Tudor (2001) highlight the importance of burial and disinterment on cobble beaches, in particular of small sized items.

Comparisons with other studies in the literature are difficult because of different sampling strategies. For example, visual counts are known to underestimate the amount of small plastic particles (Kusui et al., 2003). In spite of these caveats, average summer abundances in our study ( 31 items $\mathrm{m}^{-1}$ ) were very similar to the values reported for other Spanish beaches (33 items $\mathrm{m}^{-1}$; Gabrielides et al., 1991) but higher than the values observed at other Mediterranean locations (e.g. Golik et al., 1992). These latter differences could be attributed, among other reasons, to the proximity to populated areas. The quantity of litter on a beach is inversely related to its geographical distance from population centres and directly related to the number of visitors frequenting it (Gabrielides et al., 1991). The highest amounts of debris in this survey were collected on beaches close to Palma city which are reachable either on foot or by metropolitan transport. These areas are subject to a more intensive use since beach physical and social carrying capacities are strongly influenced by access. The former term refers to the number of individuals a beach can physically accommodate, whereas the latter is associated with the concentration of individuals - crowding perception (da Silva, 2002). Nevertheless, although the abundance of debris in this study was higher in areas close to population nuclei, there was no significant correlation between abundance and proximity to urban centres, suggesting that factors influencing nearshore currents such as beach geomorphology and predominant wind/wave direction may regulate beach pollution (Basterretxea et al., 2004). This was also indicated by PCA analysis based on the relative composition of the collected debris, in which enclosed beaches were grouped together. Environmental factors-particularly wind forcing - have been reported to be of major importance in regulating litter abundance in previous studies on islands (e.g. Corbin et al., 1993; Debrot et al., 1999; Orfila et al., 2005) and explain both the differences in litter amounts observed on nearby beaches and the accumulation in certain beach sectors.

In most studies all over the world, debris is dominated by plastics. In a review of plastic debris, Derraik (2002) reported values between 32 and 90\% of debris items represented by plastics. In the current study of the Balearics, the most important high season debris is under the category 'Other' (45\%), which includes cigarette butts, the most frequently observed item in the Balearic beaches, and plastic is only second in importance (36\%). Sociological aspects such as beach-user perception should be considered in order to understand these discrepancies. Unlike plastic objects, cigarette butts are not viewed as a major threat to the environment by smokers and are commonly buried in the sand. The relationship between plastic and smoking objects reverses in low season when, owing to the decrease in beach users, smoking objects decline considerably and plastics become predominant, accounting for up to $67 \%$ of the objects. This variation is accompanied by a change in the origin. The majority of plastic items found in high season originated from recreational activities, whereas low season objects were related to personal hygiene/medical items, possibly reaching the shore through drainage systems.

In the present study, PCA techniques revealed that most of the variability is explained by those 
groups of objects related to beach users. These observations are consistent with results of Tudor et al. (2002) who, also using PCA analysis, reported a beach-user source of debris found in the Mediterranean which is similar to litter pollution characteristics in other tourist locations around the world (e.g. the USA). These beaches, popular for recreation (and tourism), are typically marked by cigarette butts and other smokers' materials, plastic fragments, papers and food leftovers. Small differences such as increases in wood or cotton sticks may be due to local anomalies.

Locally generated litter is important in the Balearic Islands, where beachgoers in summer and drainage systems in winter are the main litter sources. Unlike other countries, where ships make a significant contribution to beach litter (e.g. Rodriguez-Santos et al., 2005), less than $1 \%$ of the items collected showed evident signs of exposure to the sea. Some of the labels (approximately 1\%) that were identified suggested foreign origins, mostly from surrounding countries such as France, Algeria and Morocco (although Korean and Greek items were also found). The Balearic Islands are in the path of large cargo, fishing and cruise vessels which can generate a portion of this litter. Additionally, inputs from leisure boats can also be important. The relative contribution of these sources and the paths which floating objects follow transported by wind and currents until they are stranded on the Balearic beaches still remain to be clarified.

\section{ACKNOWLEDGEMENTS}

This study was funded by the Conselleria de Medi Ambient of the Balearic Government. The authors would like to express their gratitude to Benjamín Casas for technical assistance and to Francisco Sobrado and Clara Llebot for their collaboration in the field work. We appreciate the comments of an anonymous reviewer which significantly improved the original manuscript.

\section{REFERENCES}

Aliani, S. and A. Molcard. - 2003a. Hitch-hiking on floating marine debris: macrobenthic species in the Western Mediterranean Sea. Hydrobiologia, 503: 59-67.

Aliani, S., A. Griffa and A. Molcard. - 2003b. Floating debris in the Ligurian Sea, north-western Mediterranean. Mar. Pollut. Bull., 46: 1142-1149.
Ballance, A., P.G. Ryan and J.K. Turpie. - 2000. How much is a clean beach worth? The impact of litter on beach users in the Cape Peninsula, South Africa. S. Afr. J. Sci., 96 (No. 2): 210-213.

Barcelona Convention. - 1976. Convention for the protection of the Mediterranean Sea against pollution. United Nations Environment Programme.

Barnes, D.K.A. and P. Milner. - 2005. Drifting plastic and its consequences for sessile organism dispersal in the Atlantic Ocean. Mar. Biol., 146: 815-825.

Basterretxea, G., A. Orfila, A. Jordi, B. Casas, P. Lynett, P.L.F. Liu, C.M. Duarte and J. Tintoré. - 2004. Seasonal dynamics of a microtidal pocket beach with Posidonia oceanica seabeds (Mallorca, Spain). J. Coastal Res., 20(4): 1155-1164.

Corbin, C.J. and J.G. Singh. - 1993. Marine debris contamination of beaches in St. Lucia and Dominica. Mar. Pollut. Bull., 26(6): 325-328.

da Silva, C.P. - 2002. Beach carrying capacity assessment: how important is it? J. Coastal Res. (SI 36): 190-197.

Debrot, A.O., A.B. Tiel and J.E. Bradshaw. - 1999. Beach debris in Curaçao. Mar. Pollut. Bull., 38(9): 795-801.

Derraik, J.G.B. - 2002. The pollution of the marine environment by plastic debris: a review. Mar. Pollut. Bull., 44: 842-852.

Dinius, S.H. - 1981. Public perceptions of water quality evaluation. Water Resour. Bull., 17: 116-121.

Dixon, T.J. and T.R. Dixon. - 1981. Marine litter surveillance. Mar. Pollut. Bull., 12(9): 289-295.

Edyvane, K.S., A. Dalgetty, P.W. Hone, J.S. Higham and N.M. Wace. - 2004. Long-term marine litter monitoring in the remote Great Australian Bight, South Australia. Mar. Pollut. Bull., 48: 1060-1075.

Frost, A. and M. Cullen. - 1997. Marine debris on northern New South Wales beaches (Australia): sources and the role of beach usage. Mar. Pollut. Bull., 34(5): 348-352.

Gabrielides, G.P., A. Golik, L. Loizides, M.G. Marino, F. Bingel and M.V. Torregrossa. - 1991. Man-made garbage pollution on the Mediterranean coastline. Mar. Pollut. Bull., 23: 437-441.

Galgani, F., J.P. Leaute, P. Moguedet, A. Souplets, Y. Verin, A. Carpentier, H. Goraguer, D. Latrouite, B. Andral, Y. Cadiou, J.C. Mahe, J.C. Poulard and P. Nerisson. - 2000. Litter on the sea floor along European coasts. Mar. Pollut. Bull., 40(6): 516527.

Galil, B.S., A. Golik and M. Türkay. - 1995. Litter at the bottom of the sea: a sea bed survey in the Eastern Mediterranean. Mar. Pollut. Bull., 30(1): 22-24.

Golik, A. and Y. Gertner. - 1992. Litter on the Israeli coastline. Mar. Environ. Res., 33(1): 1-15.

Guerra, A. - 1992. Mollusca, Cephalopoda. In: Ramos M. A. et al. (eds.), Fauna Ibérica. Museo Nacional de Ciencias Naturales CSIC, Madrid.

HELCOM. - 1974. Convention on the protection of the marine environment of the Baltic Sea area. Helsinki Convention, Helsinki Commission.

Jones, M.M. - 1995. Fishing debris in the Australian marine environment. Mar. Pollut. Bull., 30(1): 25-33.

Katsanevakis, S. and A. Katsarou. - 2004. Influences on the distribution of marine debris on the seafloor of shallow coastal areas in Greece (Eastern Mediterranean). Water Air Soil Poll., 159: 325-337.

Kusui, T. and M. Noda. - 2003. International survey on the distribution of stranded and buried litter on beaches along the Sea of Japan. Mar. Pollut. Bull., 47: 175-179.

Laist, D.W. - 1987. Overview of the biological effects of lost and discarded plastic debris in the marine environment. Mar. Pollut. Bull., 18(6B): 319-326.

MARPOL. - 1973. International convention for the prevention of pollution from ships. United Kingdom. International Maritime Organization.

Masó, M., E. Garcés, F. Pagès and J. Camps. - 2003. Drifting plastic debris as a potential vector for dispersing harmful algal bloom (HAB) species. Sci. Mar., 67(1): 107-111.

Merrell, T.R. Jr. - 1980. Accumulation of plastic litter on beaches of Amchitka Island, Alaska. Mar. Environ. Res., 3: 171-184.

Moore, S.L., D. Gregorio, M. Carreon, S.B. Weisberg and M.K. Leecaster. - 2001. Composition and distribution of beach debris in Orange County, California. Mar. Pollut. Bull., 42(3): 241-245.

Orfila, A., A. Jordi, G. Basterretxea, G. Vizoso, N. Marbà, C.M. 
Duarte, F.E. Werner and J. Tintoré. - 2005. Residence time and Posidonia oceanica in Cabrera Archipelago National Park, Spain. Cont. Shelf Res., 25: 1339-1352.

OSPAR Convention. - 1992. Convention for the protection of the marine environment of the North-East Atlantic. Paris. OSPAR Commission.

Otley, H. and R. Ingham. - 2003. Marine debris surveys at Volunteer Beach, Falkland Islands, during the summer of 2001/02. Mar. Pollut. Bull., 46: 1534-1539.

Ribic, C.A. - 1998. Use of indicator items to monitor marine debris on a New Jersey beach from 1991 to 1996. Mar. Pollut. Bull., 36(11): 887-891.

Rodrigues-Santos, I., A.C. Friedrich and F. Prado-Barretto. - 2005. Overseas garbage pollution on beaches of northeast Brazil. Mar. Pollut. Bull., 50: 778-786.

Sazima, I., O.B.F. Gadig, R.C. Namora and F.S. Motta. - 2002. Plastics debris collars on juvenile carcharhinid sharks (Rhizoprionodon lalandii) in southwest Atlantic. Mar. Pollut. Bull., 44: 1147-1149.

Silva-Iñiguez, L. and D.W. Fischer. - 2003. Quantification and classification of marine litter on the municipal beach of Ensenada, Baja California, Mexico. Mar. Pollut. Bull., 46: 132-138.

Stefatos, A., M. Charalampakis, G. Papatheodorou and G. Ferentinos. - 1999. Marine debris on the seafloor of the Mediterranean Sea: examples from two enclosed gulfs in Western Greece. Mar. Pollut. Bull., 38(5): 389-393.

ter Braak, C.J.F. and P. ?milauer. - 2002. CANOCO reference manual and user's guide to Canoco for Windows: Software for Canonical Community ordination (version 4.5). (Microcomputer Power, Ithaca, NY, USA).

Tudor, D.T., A.T. Williams, P. Randerson, A. Ergin and R.E.
Earll. - 2002. The use of multivariate statistical techniques to establish beach debris pollution sources. J. Coastal Res. (SI 36): 716-715.

Vauk, G.J. and E. Schrey. - 1987. Litter pollution from ships in the German Bight. Mar. Pollut. Bull., 18(6B): 316-319.

UNEP - United Nations Environment Programme. - 1975.

Velander, K. and M. Mocogni. - 1998. Maritime litter and sewage contamination at Cramond Beach Edinburgh - A Comparative Study. Mar. Pollut. Bull., 36(5): 385-389.

Williams, A.T., K. Pond, D.T. Tudor, H. Jansen and H.B. Liu. 1999. The robustness of litter transect data collection by different survey groups. In: E Ozhan (ed.), Proc. of the MEDCOAST 9 - EMECS 99 Joint Conference: Land Ocean Interactions Managing coastal ecosystems, pp. 715- 726, MEDCOAST, Middle East Technical University, Ankara, Turkey.

Williams, A.T. and D.T. Tudor. - 2001. Litter burial and exhumation: spatial and temporal distribution on a cobble pocket beach. Mar. Pollut. Bull., 42(11): 1031-1039.

Williams, A.T., D.T. Tudor and P. Randerson. - 2003. Beach litter sourcing in the Bristol channel and Wales, U.K. Water Air Soil Poll., 143: 387-408.

Willoughby, N.G. - 1986. Man-made litter on the shores of the Thousand Island Archipelago, Java. Mar. Pollut. Bull., 17(5): 224-228.

Willoughby, N.G., H. Sangkoyo and B.O. Lakaseru. - 1997. Beach litter: an increasing and changing problem for Indonesia. Mar. Pollut. Bull., 34(6): 469-478.

Scient. ed.: M. Masó.

Received July 20, 2006. Accepted February 20, 2007.

Published online May 23, 2007.

\section{APPENDIX}

Classification criteria for type of material and activity of origin.

\section{Type of material}
1. Plastic
2. Organic matter
3. Wood
4. Glass
5. Paper
6. Metal

7. Other

\section{Activity of origin}

\begin{tabular}{|c|c|c|}
\hline 1. Shore/recreational activities & 2. Activities in the sea & 3. Smoking-related items \\
\hline $\begin{array}{l}\text { - bags/food wrappers } \\
\text { - glasses, plates, cutlery } \\
\text { - balls } \\
\text { - tins and related items (rings, plastic holders, taps) } \\
\text { - drink bottles (plastic and glass) and tops and lids } \\
\text { - fast-food containers } \\
\text { - nappies } \\
\text { - drinking straws and decorative items } \\
\text { - clothes } \\
\text { - toys } \\
\text { - plastic filling material }\end{array}$ & $\begin{array}{l}\text { - bait wrappers or boxes } \\
\text { - fishing lines, nets and cages } \\
\text { - cleaning product bottles } \\
\text { - bulbs, tubes } \\
\text { - buoys, floaters } \\
\text { - oil, fuel bottles or containers } \\
\text { - items derived from the transport of } \\
\text { products: boxes, wrappers, } \\
\text { plastic strips etc. } \\
\text { - ropes }\end{array}$ & $\begin{array}{l}\text { - cigarettes/cigarette filters } \\
\text { - matches, lighters } \\
\text { - cigarette butts } \\
\text { - tobacco wrappers, packets }\end{array}$ \\
\hline 4. Personal hygiene/medical items & 5. Others from artificial origin & 6. Natural land/terrestrial origin \\
\hline $\begin{array}{l}\text { - syringes } \\
\text { - condoms } \\
\text { - tampons, applicators, sanitary towels } \\
\text { - cotton bud sticks } \\
\text { - plasters, lint }\end{array}$ & $\begin{array}{l}\text { - household items } \\
\text { - batteries } \\
\text { - pieces of cars, motorbikes } \\
\text { - building materials } \\
\text { - containers } \\
\text { - tyres }\end{array}$ & - branches, trunks, etc. \\
\hline 7. Marine origin & & \\
\hline
\end{tabular}

- dead animals or animal remains

- shells, etc 